\title{
See What You Hear
}

Staging Philosophy

Arno Böhler, Susanne Valerie Granzer

SusAnne Valerie (knocking at the microphone): One, two, three. Do you hear me? Do you see me?-Fine.

First of all, I would like to thank you, Charlotte, for the invitation to speak about our research activities Philosophy On Stage in front of the new association CRASSH. ${ }^{1}$

ARno BöHLER: Hello, I'm Arno. I'm a so-called philosopher because I teach philosophy at the University of Vienna, Department of Philosophy. I too would like to express my thanks to Charlotte, our host, and all the others who showed such a great interest in this new forum for Research through Art and Creativity. To start thinking with the ritualized form of thanking is maybe an intrinsic feature of artistic research. Because of the experimental, highly risky character one embraces in this discipline: Sometimes-something-works. But most of the time we are in a state of search, or even in a re-search mode in this field. One finds oneself in the dark. One learns to be a friend of the dark, of a docta ignorantia, of not knowing. Thereby one learns to be moderate.

Searching for light in the dark, over and over again. And being thankful, over and over again could be a sort of definition even of what it means to take, for example, philosophy in itself as an artistic research practice. A form of life, in which one is called to think, without knowing exactly what one is doing, while one is following such a "call".

1 This lecture performance with the title See What You Hear took place on October 12th, 2012 at the University of Cambridge. 
SusAnNe Valerie: I'm Susanne Valerie. I'm an actress. This was my personal call. I was performing in dramas for about eighteen years at state theatres in the German speaking area. Exposing myself in a dramatic way based on literary figures one could call a kind of artistic re-search practice on the human condition. Why? In common life we think we are able to see, to speak, to hear, to think, but acting forces you to learn all these things anew. On stage you are faced with the disturbing fact-as Nietzsche says in Twilight of the Idols—that "you have to learn to see, you have to learn to think, you have to learn to speak ... [you have to learn] letting things come out." ${ }^{2}$ Secondly, playing the character of somebody else, one immediately learns—on a very physical, or bodily, levelthat every conceptual personae one is staging is "padding in the same dark" as one does in real life. Both is quite a shock, but exciting too and I think it never ends being exciting.

Since 1989, I've been a university professor for acting at the University of Music and Performing Arts Vienna, Max Reinhardt Seminar and my artistic research field, together with Arno, is now what we call "Philosophy on Stage". We thereby re-enact the history of Continental Philosophy, the concepts of thinking, not only in a discursive manner, but also with our flesh within the flesh of the world. This means we try to do philosophy in an ele-mental way. Merleau-Ponty says, the flesh of a body works like an Element. Everybody is a particular part of a general elementary field. We all share IT, this element, with others-in a very physical, sensitive way.

This kind of sensitive, bodily gathering is very familiar to me as an actress. It belongs to the basics of the performing arts. Being on stage highlights this particularly well: we are no solus ipse. On the contrary: We are always connected with others-and we cannot separate ourselves from our body, our flesh, even when we are "only" involved with discursive, intellectual matters. We are a community of bodies. Our "ele-mental" body is the primary condition we are born in, the way our being takes place - and therefore our body is the indicator of how we interpret the world and our being-in-the-world, the way we think \& feel, the way we are trained and disciplined to think \& feel. We may not be aware of what shows up and maybe we would disagree with what shows up, and displace it, but the body does not care about that. It is a kind of traitor to our conditioned thinking, of our conditioned feeling, of our conditioned interpretation of the world. I

2 Friedrich Nietzsche: Twighlight of The Idols, p. 41. 
would call it— the body—an inconvenient bloody bastard and we cannot get rid of it—and personally I welcome it!

ARNo BöHLER: So this is the way one is trained in your discipline. You do research with your body and the responses it gets. This is a very unusual practice for a philosopher. One would have to deconstruct the classical picture of thinking first in order to do philosophy in such an artistic way. Because the common image of thinking that standardizes the practice of doing philosophy in the academic world all over the Globe is not used to think in an "ele-mental", bodily way. One does not work with one's own body, but with papers, with texts. Every-body knows this. One is called to submit articles, present speeches at conferences, publish books (pay fees) etc.

The forms in which one writes, speaks and behaves within these contexts are highly standardized, but the influence of these informal codes on how somebody ought to behave in the world of academia is in fact rarely conceived as being problematic. Don't speak all too lively, don't show your emotional involvement with the work you do as a scientist. The room, the light, the setting in which you present your scientific results are not relevant to the output of these results. They must work, by their very definition, independently from the conference setting in which you present your scientific results. Accept the common dress codes. Don't appear in costumes. Serve coffee, water and some sweets. Don't arrange a Symposium in Plato's sense.

Philosophers accept these informal codes mostly in a naïve way. One does not reflect on them. One just buys them as a cultural practice handed over by a certain academic tradition. These matters do not matter, since Scientists assume that these profane rituals are insignificant to the results one produces in one's science. Science, for them, is all about ideas, and not about bodily behaviours and spatial settings. They may matter for the arts, but not for scientific practices.

In accordance with Derrida I call this the mystical ground of scientific practices: One takes the ideas of Plato as something that is interesting. They still may count today, but not the setting in which Plato presented his ideas: In a Symposium, sometimes outside, sometimes inside the city walls, on the market place etc. Who cares about such issues nowadays? And when one does? One just cares about such questions in a discursive manner. One writes a book on the significance of these places Plato chooses in his work, but one presents this book afterward in a conference at a University, very critically, but well dressed, 
drinking coffee from the conference table and eating the readily available sweets, which one finds there etc. etc. etc.

Philosophy on Stage ${ }^{3}$ questions such practices. It creates new room and surroundings, a territory, in Deleuze's sense, in which new thoughts are possible to occur due to the new corporeal surrounding, in which one is indeed thinking.

I would like to show you a typical example of the commonly shared image of thought by presenting you a short interview-passage with Gilbert Ryle, a famous British professor of philosophy who taught in Oxford. He is generally perceived to be an important representative of British ordinary language philosophy. Sometimes he is also labelled a behaviourist.

I think this film-passage speaks for itself. It is part of a film produced by the Austrian film director Ferry Radax in 1973/74 with the title "Biographical and Philosophical Investigations." [Could you please start screening it.]

\section{FILMSCREENING}

(TC II:40- I2:I7)

FerRy RadAX: „Ich bin mir nicht sicher, ob Professor Ryle zustimmen würde. Er war ein Schüler Wittgensteins in Cambridge und lehrt jetzt Philosophie in Oxford." ["I'm not sure whether Professor Ryle would agree. He was a student of Wittgenstein in Cambridge. Now he teaches philosophy in Oxford.” Translation A.B.]

Gilbert Ryle: “I don't think we have lost very much by not having his voice. Of course, concerning Wittgenstein himself his voice is an interesting thing-as an expression of Wittgenstein as a person. But with regard to Wittgenstein as a philosopher, I would say, go to his writings."

3 Zum Philosophie und Performance Festival Philosophy on Stage \#3 siehe: http://homepage.univie.ac.at/arno.boehler/php/?page_id=841 (Mediathek) und: http://homepage. univie.ac.at/arno.boehler/php/?page_id=1244 (Forschung) vom 25.1.2014. 
ARno BöHLER: I would say that Gilbert Ryle here presents us with a very common picture of what it means to do philosophy in a scientific manner. Philosophy is primarily not concerned with the staging of the voice of a person, or the life of a philosopher. It is rather a matter of making use of one's ordinary language in a more sophisticated, logical, or what Nietzsche called, Socratic manner. When Wittgenstein, for instance, uses the word "drill"- "abrichten" to denote the praxis of how one learns a certain language game indeed, the word "drill" matters as a written expression of the philosophical form of life he developed in his writings, but the "almost brutal drill", he showed in his behaviour as a village teacher against the school-boys he taught is not part of, or an expression of his philosophical form of life. Wittgenstein's texts, Ryle says later, remain for all times. But his voice has gone. But does it therefore count less?

Susanne Valerie: This utterance of Gilbert Ryle puzzled me, when I first heard it. His neglect of a person's voice sounds strange, even curious to me-as if one would sterilize or unsex a person. Actors emphasize the voice and the body and all its expressions. This includes the emotions of a character, his thoughts, his subconscious and his conscious mind. The whole being of a person is of the highest interest for the performing arts. It is the medium and challenge of acting. Therefore, working within a wide range is an obligation or, as I prefer to say, it is the playground of our artistic work. Nothing can be neglected.

Every single voice is unique and full of information about this very unique person. So, from the point of view of acting, the voice with its singular tonality tops the written word in its discursive quality and meaning. On stage, language is not only a matter of scientific knowledge and understanding, but also a matter of vivid vibration from top to toe-and besides tonality it has a subversive power. It can rewrite words, change their meaning, transport unspoken thoughts or reveal subconscious or hidden emotions. Intended. Unintended. Nonsense or stupidity can change to wisdom and so-called wisdom can be uncovered as stupidity. Even silence-which is always part of the spoken language-has a "linguistic" power. Similar to tonality silence makes audible what a person is only thinking or feeling, or what cannot be expressed and reached by words. In a certain kind of silence you can even hear the abyss of an uncanny nothingness or the generous welcome of nothingness. 
ARNo BöHLER: Will things change if we start to understand philosophy as an artistic research practice? Has "Continental Philosophy" not always been a kind of artistic research practice already?

Socrates, as you may know, never wrote a single piece of text. Heidegger therefore called him the purest of all philosophers. Michel de Montaigne wrote essays to perform philosophy. Plato wrote dramas and dialogs. Nietzsche wrote philosophical aphorisms and philosophical poetry such as "Thus spoke Zarathustra", Wittgenstein introduced a new style of writing to present his philosophical investigations, Heidegger used Ordinary Language in an extraordinary manner in order to express his thoughts in a unique style. None of them would be described as disciplined and academically trained philosophers judging by today's standards. They do not match the match of today's publication and evaluation criteria at all. They are all "queer-reviewed" philosophers.

But is a purely formalized mathematical language indeed the proper way of speaking, for example, on friendship? Or is Montaigne not right to write about friendship in an essayistic style rather than a formal one?

Staging Philosophy tries to give such outcasts a strong voice within the realm of today's philosophies. But there are many possibilities to be critical of the monopolization of a certain image of thought and style of writing in this new discipline, in which we stage philosophy. In which we see philosophy as an artistic research practice. As "künstlerische Forschung".

Understanding philosophy in an undisciplined way of doing science in the neighbourhood of the arts is not a fashionable new approach to found a new discipline. It is rather a re-consideration of the artistic value that traditionally has been established in the old fashioned way Old Europe was doing philosophy for more than two thousand years. Staging Philosophy would thus be a new movement of finding new territories to do Continental Philosophy within the new historical demand of a postmodern world. Thereby one has to re-open Pandora's box, because literarily, the word philosophy indicates a mode of desire, and not a scientific neutral standpoint. It is a form of philein, a form of being affected by others and affect others in a mode that is governed by sophia, a female form of wisdom. Finding territories for such an image of thought is the re-search mode philosophy is longing for when it tries to stage philosophy.

Look at this body here. This is the concrete material I have to make use of when I want to go to Cambridge.-A gendered body, born in Austria-So, from the point of view of philosophy AS being an artistic research practice, as a mode of staging philosophy on an ele-mental level, the singularity of the tone of a voice is, in itself a "truth value". 
Susanne Valerie: As an actress I am trained in an “anti Rylian” sense. This makes a lot of things easier for an artist. In particular, actors have-fortunately-the benefit of a kind of jester's license in our society. I confess I enjoy it. This gives you more freedom. For example, it gave me the freedom to get a Ph.D. in Philosophy-and I did want to study Philosophy, as in my field, in the community of actors, I sense a lack of interest, and therefore a lack of opportunity, in reflection. This proved a problem for me, because from the outset of becoming an actress I cared about the relationship between acting on stage and asking existential, philosophical questions. For instance: What happens during acting on stage with the body, the mind, the affects, what does it mean to speak, to keep silent, to hear, to listen, to answer, to look, to look into the partners eyes, to move, and so on and so forth. Even what it means to die... especially as all the parts I performed during my i 8 years on stage are all gone, have all vanished. Therefore, the very last performance is always a kind of death you are suffering from.

\section{Karl Valentin Am Heuboden ${ }^{4}$}

Having spoken her last sentence, Susanne opens the big, silver suitcase which all the time from the beginning could be seen behind the two lecturers and does usually not belong to the setting of rooms at a university. She takes out two trenchcoats, two grey Borsalinos and two pairs of leather gloves, one in black and one in a gaudy red. They put on the trenchcoats and the leather gloves, she the red pair and he the black pair, and both put on the hats. In no time the atmosphere has changed. Now, instead of classical lecturers we see two characters-or, if you like, two caricatures-from a 1950 gangster film, smiling broadly to the audience.

Susanne Valierie: Now, we would like to invite you all to join us to 'pad in the dark'. Therefore, we prepared blindfolds, which you can find at the back of your chairs. So please, if you would be so kind as to cover your eyes with them, so that you see nothing, because you are about to hear a conversation between two

4 Karl Valentin: Sämtliche Werke. Band 4: Dialoge, (C) 1996 Piper Verlag GmbH, München. Abdruck mit freundlicher Genehmigung des Piper Verlages. 
good-for-nothings who meet in the darkness at a hayloft. It's a short piece written by the Bavarian comedian and performer Karl Valentin.

All those present are ready to join, they put the blindfolds on, and finally the whole audience wears black blindfolds around their heads. This does not only make an unusual image for a university audience, but out of the blue this action has changed everybody's head posture, and on the whole the bodies signal increased tension. Obviously it is true that one does not see anything through the blindfolds, and due to the loss of the familiar sense of sight the whole body concentrates automatically on hearing, on listening.

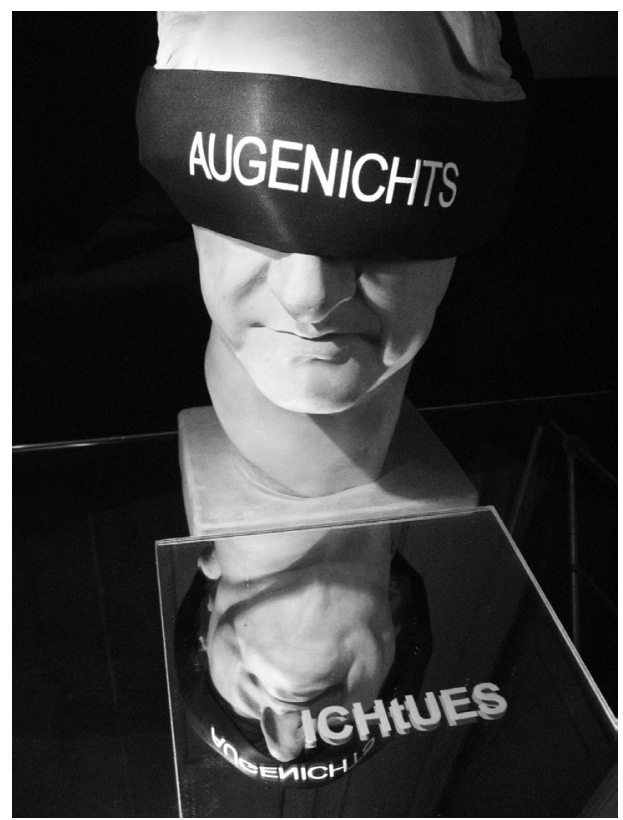

Hans Hoffer: Augenichts (2014). Blindfolds produced by Hans Hoffer for "See What You Hear".

Susanne Valerie: Thank you. Thank you dear all. 
[For legal reasons, what we print here is the original, German version of Karl Valentin's text: "Am Heuboden ". At the University of Cambridge and the University of Surrey the text was spoken in a Scottish-English dialect.]

Anni: Simmerl, Simmerl! wo bist denn?

Simmerl: Do!

Anni: Wo?

Simmerl: Do!

Anni: I seh Di ja net[.]

Simmerl: Desweg'n bin i do da[.]

Anni: Ja hörn tua i Di scho', aber seh'gn tua i Di net[.]

Simmerl: Ja dös sell ko' i scho' versteh, weilst halt im Finstern nix siehst[.]

Anni: Aba warum hört man nacha im Finstern was?

Simmerl: Ja warum? Hörst Du ebba jetzt grad was?

Anni: Freili'! Di hör i[.]

Simmerl: Warum grad ausg'rechnet mi?

Anni: Weil halt sunst wahrscheinli neamand da is[.]

Simmerl: Ja woasst Du dös g'wiss?

Anni: Freili woass i dös g'wiss, sunst tat i do ausser Dir no ebbs hör'n.

Simmerl: Hörst Du mi denn a, wenn i nix red?

Anni: Sell woass i net, red amal nix, ob i nacha was hör[.]

Simmerl: Ja jetzt pass auf, jetzt red i nix - Hast dös jetzt g'hört, wia i nix g'redt hab?

Anni: Ja tadellos - und dös hab i nacha a g'hört wiast d' g'sagt hast: »hast dös g'hört, wia i nix g'redt hab?[«]

Simmerl: So, dös hast g'hört? - Aber des andere net?

Anni: Was für a anders?

Simmerl: No ja, wia i nix g'redt hab[.]

Anni: Na, zuaghört hab i scho', aber g'hört hab i nix[.]

Simmerl: Dös is g'spassig, gell, mit dera Hörerei!

Anni: Ja, dös is wohl g'spassig. - Du Simmerl! probiern ma dös gleiche mit’n sehn a, statt mit'n horch'n, schaug amal net, ob i Di na seh?

Simmerl: Ja is scho recht, jetzt schaug i amal net - - jetzt hab i net g'schaut, hast mi g'sehn?

Anni: Na!

Simmerl: Hast mi wirklich net g'sehn?

Anni: Na g'wiss net, i hab Di ja z'erst a net g'sehn wiest g'schaut hast.

Simmerl: Was? Da hast mi a net g'sehn? 
Anni: $\mathrm{Na!}$

Simmerl: Ja wo hast nacha da hing'schaugt?

Anni: Nirgends[.]

Simmerl: Warum hast denn dann nirgends hing'schaut?

Anni: Ja wo hätt i denn sonst hinschau'n soll'n?

Simmerl: Ja mei, zu mir her hätt'st schaun soll'n[.]

Anni: Im Finstern seh i Di do net[.]

Simmerl: Ja warum net?

Anni: Wenn Du dös net woasst, wia soll's denn dann i wiss'n? Wo i doch viel dümmer bin als $\mathrm{Du}[$.

Simmerl: Na Anni, dös kannst a net sag'n, mir zwei san scho' gleich dumm, sunst kunnt ma net so saudumm daherred'n.

Anni: War dös sau[d]umm, was mir jetzt grad gredt ham?

Simmerl: Na ganz saudumm no net[.]

Anni: No net? - Was is denn nacha ganz saudumm?

Simmerl: Ganz saudumm wär z. B. dös, wenn i zu Dir g'sagt hätt' - Anni! Halt Dir amal d'Ohr'n zua, dann schaug i ob i Di riach.

Anni: So, dös is ganz saudumm?

Simmerl: Ja, dös wär ganz saudumm!

Anni: O mei bin i saudumm, dass i net amal g'wusst hab, was ganz saudumm is[.]

Without the audience noticing, who still cannot see anything due to wearing blindfolds, the two performers, while speaking the last sentences, have taken two donkey heads from the suitcase; they put them on ...

SusAnNe Valerie: Thank you for listening.-Now you may put off the blindfolds.

The people in the audience take off the black blindfolds-to now see two donkey heads standing before them in the lecture hall.

Laughter. 


\section{Bibliographie}

Nietzsche, Friedrich: Twighlight of The Idols, Oxford: Oxford University Press I998.

Valentin, Karl: Sämtliche Werke. Band 4: Dialoge, München: Piper Verlag GmbH i996. 